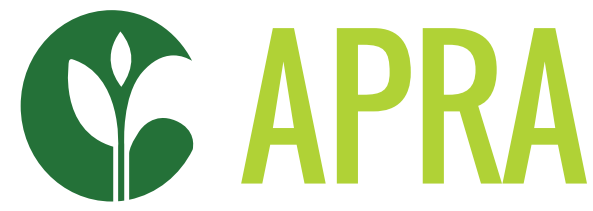

Agricultural Policy Research in Africa

\title{
HOW DOES LAND SIZE MEDIATE THE RELATIONSHIP BETWEEN SPECIALISATION AND COMMERCIALISATION? LESSONS FROM RICE FARMING IN THE FOGERA PLAIN OF ETHIOPIA
}

Rachel Sabates-Wheeler, Marco Carreras and Dawit Alemu 


\section{CONTENTS}

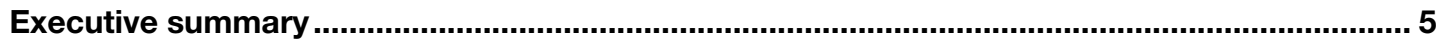

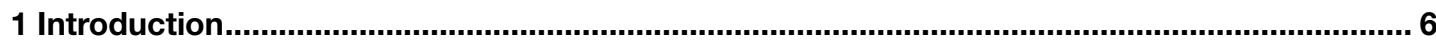

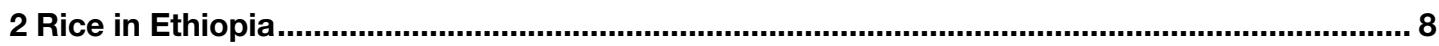

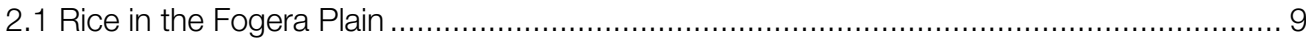

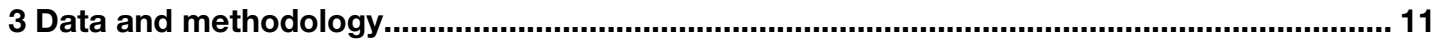

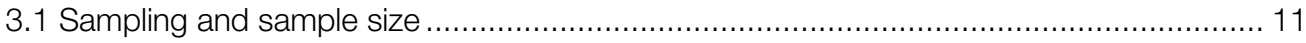

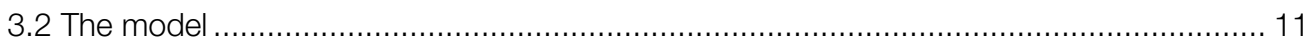

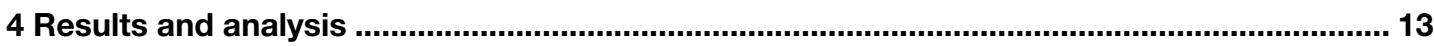

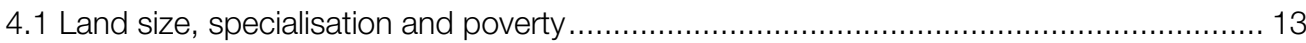

4.2 Determinants of rice commercialisation: a story about specialisation? ........................... 14

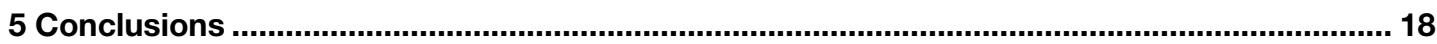

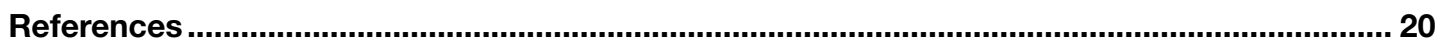

Appendix

\section{List of tables}

Table 2.1: Characteristics of rice cultivation in the Fogera Plain ...................................... 10

Table 3.1: List of variables included in the vectors......................................................... 12

Table 4.1: Individual and household characteristics, by land size categories........................ 13

Table 4.2: Household and agricultural characteristics, by rice commercialisation

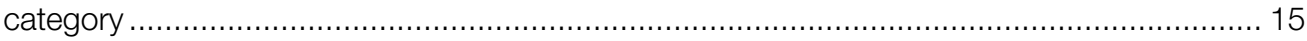

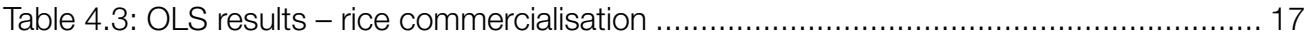

\section{List of figures}

Figure 2.1: Trends in domestic production, import and consumption ................................ 8

Figure 4.1: Relationship between land ownership and rice specialisation ............................. 14

Figure 4.2: Relationship between $\mathrm{RCl}$, rice specialisation and land ownership..................... 16 


\section{ACRONYMS}

APRA

Agricultural Policy Research in Africa

CSA

Central Statistical Agency

DA

development agent

MPI

Multidimensional Poverty Index

OLS

ordinary least squares

PSNP

Productive Safety Net Programm 


\section{ACKNOWLEDGEMENTS}

We thank the smallholder farmers, development agents and agricultural experts at district and zonal level in the Fogera Plain region, South Gondar Zone, Amhara Region, Ethiopia for their support in providing responses to our questions and facilitation of the data collection.

Rachel Sabates-Wheeler is a Development Economist and Research Fellow at the Institute of Development Studies (IDS) at the University of Sussex. She is one of the research directors for APRA. Marco Carreras is a Development Economist working at IDS and a member of the APRA consortium. Dawit Alemu is Country Representative of the Stitching Wageningen Research Ethiopia office. He is also a member of the Future Agricultures Consortium (FAC) and Country Lead of the APRA programme in Ethiopia.

This working paper is funded with UK aid from the UK government (Foreign, Commonwealth \& Development Office - FCDO, formerly DFID). The opinions are the authors and do not necessarily reflect the views or policies of IDS or the UK government. 


\section{EXECUTIVE SUMMMARY}

The introduction of rice into Ethiopia provided a solution to food insecurity. More recently, national policy has emphasised the positive relationship between rice specialisation and commercialisation and, thus, higher incomes. In retrospect, this initiative has been hugely successful as the regions where rice has been introduced have been transformed from heavily relying on food aid to becoming a thriving commercial centre. This transformation owes much to the increase in the production, consumption and commercial value of rice. However, the relationship between specialisation and commercialisation is far from straightforward and is mediated by poverty, as proxied by farm size in this paper.

Using a novel cross-sectional dataset of rice farmers from the Fogera Plain in Ethiopia, collected in 2018, in this paper we look at the relationship between rice specialisation and commercialisation and how specialisation and commercialisation decisions and outcomes are mediated by farm size. Specifically, we characterise farmers by the extent of rice specialisation and commercialisation and explore the role of landholding size. We explain a seeming paradox: that farmers with very small amounts of farm land devote high proportions of their land to rice production (that is, they are high specialisers), yet, display low levels of commercialisation. We argue that this negative relationship between specialisation and rice commercialisation is being driven by small holders who are, on average, poorer. They have little choice but to cultivate a larger share of the land to rice due to economies of scale and farming economies with respect to rice. Yet, the majority of that rice production is to satisfy domestic consumption and household food security, with only a small surplus being sold. The high commercialisers have bigger land sizes and farm a relatively small proportion of their land with rice (yet, in absolute terms this can be larger than the amount sown by smaller farms). These bigger farms cultivate rice for commercial, profit purposes. This suggests that there are distinctly different stories and behaviours driving the rice cultivation and commercialisation trajectories of smaller, poorer landowners, and larger, more wealthy ones.

This has implications for how to promote equitable access to gains from commercialisation strategies. Policy options for the smallholders include facilitating access to irrigation and the land rental market, provision of credit, and rice intensification support. 
Since the early 1970s, Ethiopia has held out high aspirations for the introduction and specialisation of rice production in terms of its impacts on both food security and income, through increasing commercialisation. This paper investigates the relationship between rice specialisation and commercialisation for farmers in the Fogera Plain in Ethiopia. The historical emphasis on the advantages of crop specialisation, in regard to rice in Ethiopia, mirrors an international debate over the trade-off between specialisation and diversification. Those urging specialisation in production do so under the assumption that factors flow with comparative ease and in accordance with comparative advantage to ensure a profit maximising outcome. In reality, smallholders face constraints and challenges in the production process due to a whole range of market failures and imperfect information and this can lead them to cultivate a diversified crop portfolio as a way of insuring themselves against food insecurity in future periods (Hardaker, Huirne and Anderson, 1997).

Agricultural commercialisation occurs when agricultural enterprises and/or the agricultural sector as a whole rely increasingly on the market for the sale of produce and for the acquisition of production inputs, including labour. For our case of the Fogera Plain we are interested in what Poulton (2017) identifies as the first phase of agricultural commercialisation - when smallholder farm households shift from semi-subsistence agriculture to production primarily for the market - in the process coming to rely increasingly on purchased inputs and sometimes also labour in their production. ${ }^{1}$ However, their scale of production remains small, due primarily to high demand for land among people who have yet to obtain more remunerative and reasonably secure employment in the non-farm economy.

The rationale for promoting agricultural commercialisation is embedded in standard agricultural economics and, as pointed out by Collier and Dercon (2009), rests on three principles. First, both growth and poverty reduction will have to start from agriculture; second, smallholder agriculture is relatively efficient in what it does and; third, commercialisation relies on improvements in technology as well as the functioning of markets (such as for inputs, credit, and output). If this potential can be unlocked, growth in agriculture and, from this, growth in the rest of the economy, will follow. While these principles have not gone unchallenged (Collier and Dercon, 2009), specifically in relation to farm size and institutional form, the role of agricultural commercialisation has been widely recognised as crucial in fostering productivity and reducing poverty (Poulton, 2018; Djurfeldt et al., 2019), yet, with associated risks in terms of food security and price volatility (Wiggins et al., 2014; Isinika et al., 2020). At the same time, access to, and extent of participation in, the market in early phases of commercialisation is limited by minimum endowments in terms of assets equipment, skills, knowledge of market and transport (Carter and Barrett, 2006; Gebremedhin and Jaleta, 2010; Saha, Sabates-Wheeler and Thompson, 2021). Participation is further inhibited for the poorest farmers by the risk of market and price fluctuations that could undermine household food security.

The discussion about the role of farm size to ensure agricultural commercialisation and growth in Africa has received plenty of attention over the years specifically questioning whether Africa should promote largescale farms or smallholder farming to spur agricultural commercialisation and growth (Collier, 2008; Chapoto, Mabiso and Bonsu, 2013). The existing literature presents diverse views. Some authors argue that priority should be given to large-scale commercial farming and to the promotion of land consolidation if Africa is to spur agricultural commercialisation and growth (Collier, 2008; del Prete et al., 2018). Others support the traditional claim that "small is beautiful" based on the evidence that small farms present higher productivity compared to large farms (Fan and Chan-Kang, 2005) and others present the relationship between farm size and agricultural productivity as a U-shaped trend, where up to certain level there is an inverse relationship followed by a positive relationship (Das and Ganesh-Kumar, 2017; Muyanga and Jayne, 2019). In relation to the optimal size of land for rice production, a study by Anang, Bäckman and Rezitis

1 The second phase refers to the process where smaller farm households are replaced by medium to large farms that are purely commercial in nature. 
(2016) argued that farm size had a positive effect on scale efficiency for smallholder rice farmers in northern Ghana.

Moreover, the role of agricultural specialisation and diversification for enhanced agricultural commercialisation and growth has also received substantial attention in the agricultural development literature. Some argue that market-based agricultural specialisation serves as a pathway for enhanced market participation and agricultural growth (Evenson and Gollin, 2003), while others argue that marketbased agricultural diversification ensures production of a variety of crops to meet market demand at different times of the year, which can ensure increased household income and profit (Ulimwengu and Badibanga, 2012). Bellon et al. (2020) suggest that it depends on the farmer's specific contexts as to whether they benefit more from a diversification or a specialisation agricultural strategy for managing their agricultural systems effectively for improved livelihoods.

Using a novel cross-sectional dataset of rice farmers from the Fogera Plain in Ethiopia, in this paper we look at the relationship between rice specialisation and commercialisation and how commercialisation decisions and outcomes are mediated by farm size (we argue that this is a proxy for poverty). Specifically, we characterise farmers by the extent of rice commercialisation and assess whether highly specialised farmers are also reporting higher levels of rice commercialisation. Our motivating question for the case of the Fogera Plain is to ask how successful has the push on rice specialisation been on enabling smallholders to engage with the market (become more commercialised)? And, has farm size affected the ability of the famers to reap the commercial advantages of rice cultivation? In addition, we explain a seeming paradox: that larger farms cultivate rice for commercial, profit purposes without obviously specialising in its production, while farmers with smaller farm sizes devote high proportions of their land to rice production (that is, they are high specialisers), yet, display low levels of commercialisation (engagement with the market). Farmers with higher rice commercialisation levels are typically larger landowners who farm a relatively small proportion of their land with rice (yet, in absolute terms this can be larger than the amount sown by smaller farms). We hypothesise that this negative relationship between specialisation and rice commercialisation is being driven by smallholders who are, on average, poorer. Poorer farmers with smaller farm sizes (below 1ha) cultivate a higher proportion with rice in order to satisfy domestic consumption and household food security, with only a small surplus being sold. This suggests that there are distinctly different stories and behaviours driving the rice cultivation and commercialisation trajectories of smaller, poorer landowners, and larger, more wealthy ones. This has implications for interventions and policy in the rice sector in Ethiopia. 
The introduction of rice in Ethiopia was linked with the quest for addressing food security and resettlement policy priorities during the Derg regime (1974-1991). Rice production created new opportunities for smallholder farmers who started cultivating it, first as a food security crop, but later as a commercial crop, mainly in areas where other crop production was not possible - such as in the Fogera Plain.

Much more recently, as evidenced in the 2010 National Rice Research and Development Strategy (MoANR, 2010), rice has become framed by the government and donors as a commercial commodity linked with increased domestic demand. ${ }^{2}$ Consequently, farmers started to intensify rice production in the lowland areas. Despite this policy push, the growth of domestic production remains far below the increase in national consumption, which has resulted in a dramatic decline of the level of self-sufficiency. As shown in Figure 2.1, the data from 2019 indicates that total domestic consumption has exceeded 700,000t (2019), which is predominantly covered by imports (76 per cent of the total consumption). The level of domestic production only reached 172,000 t, of which the Fogera Plain contributes approximately $70-80$ per cent of the national rice production.

The increased importance of rice in terms of local production, processing and marketing has resulted in the change of household consumption patterns. The average per capita consumption of rice increased from $1.17 \mathrm{~kg}$ in 2009 to $4.77 \mathrm{~kg}$ in 2017 at national level (Teamir, 2019). In the Fogera Plain consumption patterns have shifted markedly from food and local beverages (Tela and Areki) made from other cereals to rice-based food and drink. Injera is now commonly prepared by mixing teff with rice flours (up to 40 per cent), and the local beverages (Tela and Areki) are commonly prepared from rice (Sabates-Wheeler, 2018).

Regarding the productivity and commercial attractiveness of rice, the average yield for teff (which can also be grown in the Fogera Plain) in 2018 was 1.8t/ ha, whereas for paddy rice it was 2.9t/ha (CSA, 2018). The average price over the same year was 17,859 Ethiopian Birr/t for teff and 14,268 Ethiopian Birr/t for paddy rice (Data from Fogera office of Agriculture).

\section{Figure 2.1: Trends in domestic production, import and consumption}

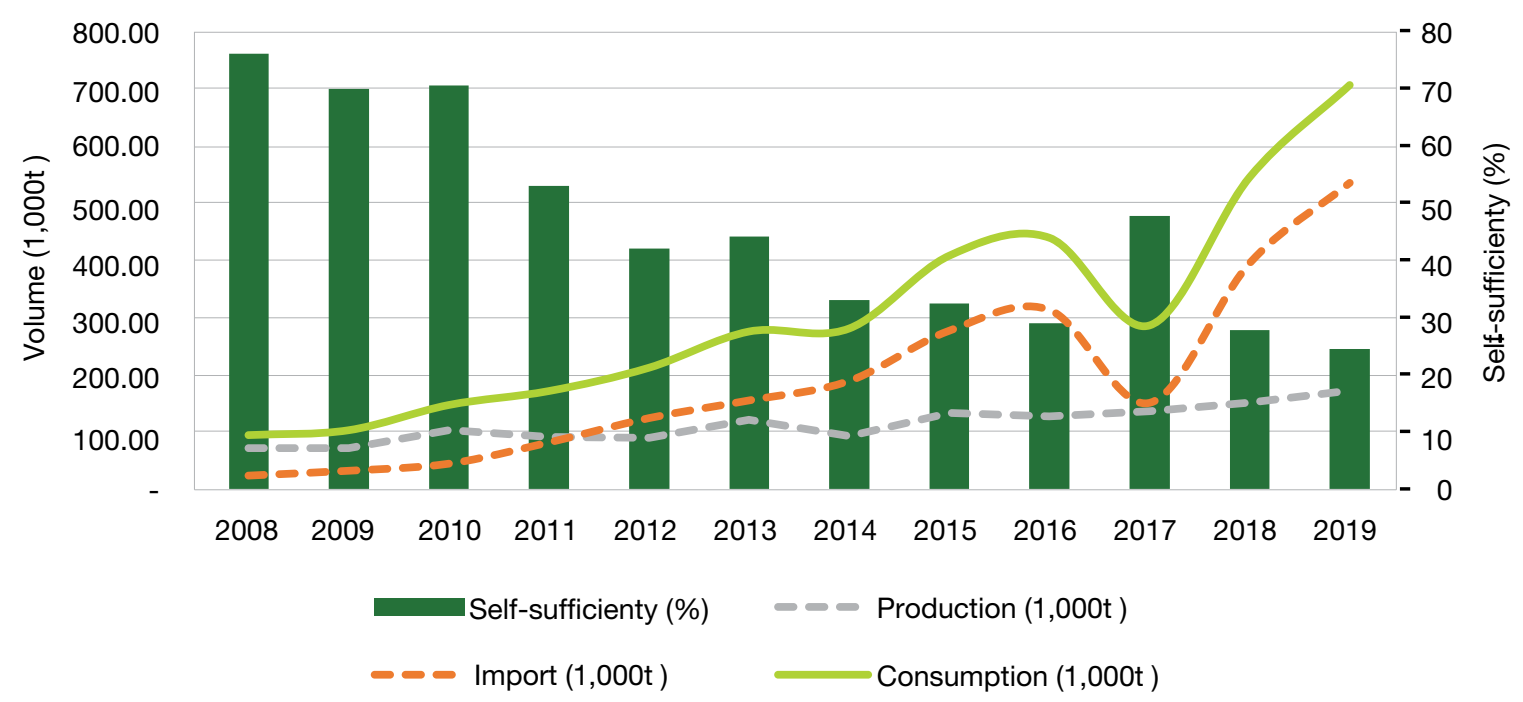

Source: Authors' own, based on data from CSA and Ethiopian Ministry of Revenue (2008-2019)

2 This strategy was developed by the government with the support of donors, mainly the Government of Japan. 
Accordingly, there is a difference in the gross margin of 8,690 Ethiopian Birr/ha. ${ }^{3}$ Due to the higher productivity of rice compared to other cereals, farmers with smaller land holdings tend to allocate more of the land for rice to ensure household food security requirements compared to those with larger farm size who mainly target production for market.

\subsection{Rice in the Fogera Plain}

Historically, much of the lowland area of the Fogera Plain was waterlogged and used for grazing, with limited opportunities for farmers to grow crops. It was the introduction of rice, mainly as a strategy for helping to alleviate food insecurity in 'hot spot' areas, that enabled farmers to cultivate a range of crops and become food secure (Alemu et al., 2018). In the early years of rice introduction, this region was characterised by high levels of poverty, and was heavily dependent on food aid stored and distributed locally from one of the warehouses of the Emergency Food Security Reserve Administration (Shahidur and Lemma, 2011). As a staple crop, the adoption of rice by farmers in the area was seen as a way to ensure food security. Similarly in the 1980s, during the Derge regime, the promotion of rice in other areas, especially in settlement areas like Pawe and Gambella areas, was associated with the necessity of ensuring food security for those resettled from the most drought affected areas.

Now, some 50 years on, the Fogera Plain is a major rice-growing area and a thriving region with low overall levels of food insecurity. As reported by Jaleta, Gebremedhin and Hoekstra (2009), rice has become an important market-oriented crop, with about 72 per cent of households in this region producing rice on approximately 44 per cent of the total cultivated land. However, they also found that among the households that produced rice, they did so on an average of 0.62 ha of land. In other words, rice was and remains a predominantly smallholder crop in the area. CSA (2019) shows that the Amhara region, where Fogera Plain is found, covers 69.4 per cent of the total rice land in the country.
In accordance with the far-reaching land reforms in the country, farm sizes in the Fogera Plain have been declining, although there has been emphasis, nonetheless, on allocating land to landless youth. ${ }^{4}$ Since the 1970s there have been three episodes of public land re-allocations/redistribution (Alemu and Berhanu, 2018). The first was during the Derge regime (1974-1991), the second was during the Ethiopian People's Revolutionary Democratic Front regime in 1997 and the third wave was during the 2008 distribution of communal lands (grazing lands) for landless youth. The land reforms constituted land redistributions from larger farm owners to smallholders and the landless, causing average farm sizes to reduce significantly. Alongside the reduction in land size, farmers began to i) specialise more into commercial commodities like rice, ii) invest in productivity enhancing inputs like irrigation and, iii) engage in land markets through either sharing cropping and/or land leasing.

In relation to the region of our study, the three districts of the Fogera Plain (Dera, Fogera and Libokemkem) used to be classified as food insecure districts annually receiving food aid managed by district office of food security and emergency. However, following the introduction of rice and its gradual expansion and commercialisation, Fogera and Dera districts and the rice producing kebeles (villages) of Libokemkem are considered food secure. Reflecting this change, since 2003, the respective offices of food security and emergency have been superseded by the office of Early Warning and Response. Libokemkem district is still considered food insecure as it belongs to the Productive Safety Net Programmes (PSNP) which provides regular support to the chronically food insecure households - mainly in kebeles that are not engaged in rice production. ${ }^{5}$ With the ongoing effort of promoting upland rice, the food security situation in the Libokemkem district of the Fogera Plain is expected to change significantly in the coming years. ${ }^{6}$

Table 2.1 presents the characteristics of rice cultivation in the Fogera Plain mainly in terms of land allocation, input use, and production. The average land size

3 The gross margin is the different total revenue and total cost of production.

$4 \quad$ The sequence of land redistribution made in the Fogera Plain has resulted in the continuous reduction of the size of farmland per farmer. In parallel, with the increase of population, there is a growing number of landless householders, especially youth. In an effort to ensure the transfer of land from less effective user to effective user, there is a provision of short-term land leasing and sharing among farmers. Due to prevalent disputes in this short-term land market, there is regulation making it mandatory to get any land sharing or leasing arrangements registered locally.

5 In 2019, there were 13,770 chronically food insecure households from close to 40,000 the estimated total number of households in Libokemkem district under the PSNP support program getting support either in the form of food for work or food aid.

6 This expectation is obviously dependent on the current unrest that the country is facing. 
Table 2.1 Characteristics of rice cultivation in the Fogera Plain

\begin{tabular}{|c|c|c|c|}
\hline $\begin{array}{l}\text { Production } \\
\text { characteristics }\end{array}$ & Indicators & Mean $(\%)$ & Std. deviation \\
\hline \multirow[t]{3}{*}{ Land allocation } & Plot size allocated for rice (ha) per farmer & 0.72 & 0.40 \\
\hline & Number of plots cultivated for rice per farmer & 2.62 & 1.36 \\
\hline & Average proportion of land allocated for rice (\%) & 62.00 & - \\
\hline \multirow[t]{2}{*}{ Input use } & Proportion of famers using hired labour (\%) & 55.30 & - \\
\hline & Access to extension service (\% of farmers) & 74.00 & - \\
\hline \multirow{3}{*}{$\begin{array}{l}\text { Land market } \\
\text { participation }\end{array}$} & Renting and sharing out own land (\% of farmers) & 23.5 & - \\
\hline & Do not participate in land market (\% of farmers) & 17.2 & - \\
\hline & Renting and sharing out own land (\% of farmers) & 59.3 & - \\
\hline \multirow[t]{5}{*}{ Production } & Total production in 2017 meher $^{7}$ season per farmer (qts) & 27.81 & 18.37 \\
\hline & Stock before Meher season harvest per farmer (qts) & 2.68 & 3.76 \\
\hline & Total available stock after 2017 harvest per farmer (qts) & 30.57 & 20.17 \\
\hline & Productivity (qts/ha) & 38.48 & 15.19 \\
\hline & Amount used for household consumption (qts) & 8.00 & 6.86 \\
\hline
\end{tabular}

Source: Authors' own, using data from an APRA Rice farmers' survey (2018)

allocated for rice is estimated to be 0.72 ha with, on average, 62 per cent of land allocated to rice and the average number of plots at 2.62 per farmer. In terms of input use, 55.3 per cent of rice farmers use hired labour for timely accomplishment of required activities mainly ploughing, weeding, harvesting and/or threshing. About 59 per cent of the rice farmers reported renting out land (either sharecropping or leasing) and about 25 per cent renting in land. On average, a rice farm household produced 28qtls of rice per year with average productivity level of 38.48 qtls/ha. Further plot level analysis shows that those who produced rice using irrigation experienced a 48 per cent increase in production per unit area compared to those who did not use irrigation. Those who applied Urea fertiliser at the recommended rate (100kg or above/ha) achieved a yield advantage, on average, of 17 per cent. 
The data for this study are derived from a household survey conducted in 2018 in Ethiopia by the APRA consortium. ${ }^{8}$ The APRA household survey used a structured core questionnaire to collect data from households concerning plots cultivated, crops grown and sold, and incomes. The questionnaire also asked for extensive information on other topics, including household characteristics, asset ownership and values, household income sources, and key questions in relation to multidimensional poverty. Data from each household were collected through face-toface interviews with the household head, and where the head was not available, we interviewed a family member with relevant knowledge of survey questions. Interviews were carried out by a team of enumerators who were trained and supervised by the researchers. Use of a core set of questions to collect specific commercialisation and outcome indicators are detailed in Chirwa, Sabates-Wheeler, and Saha (2018).

\subsection{Sampling and sample size}

The sampling followed a stratified sampling procedure, where we considered woreda, kebele and village strata to select randomly respondent farmers. Given the importance of rice and observed agrarian changes in the whole Fogera Plain, all the three rice producing districts (woredas) in the Fogera Plain were considered. A total sample of 722 households was split between these districts accounting for the total land allocated by considering proportion to population. Approximately 64 per cent of the rice land in the Fogera Plain was found in Fogera district, 28 per cent in Libokemkem District and the rest, 8 per cent, in Dera district. This translated to 470 respondents from Fogera district, 199 respondents from Libokemkem and 53 respondents from Dera district.

In order to select randomly, the number of villages to be selected were further determined considering the proportion of land allocated, accordingly, using the total list of kebeles engaged in rice production for each of the districts, 13 kebeles from Fogera, six kebeles from Libokemkem, and two kebeles from Dera district were selected using systematic random sampling. Given the similar population of farmers per kebele (around 1,000 farmers/kebele), an equal number of 35 sample farmers was selected for each kebele. The last stage again required systematic random sampling to select respondent farmers using the list of farmers at kebele level. Accounting for unavailability and refusal to participate in the survey, the sample size at kebele level was increased to 37 for each kebele. The selection of farmers was made by APRA research team members with the assistance of the field guides. The guides were development agents (DAs) working in each of the kebele as extension agents. The DAs assisted the survey not only by providing the list of farmers in each kebele, but also by fixing appointments with the selected farmers and determining the contact place and time.

\subsection{The model}

In this analysis, we are interested in the relationship between commercialisation and specialisation for rice farmers in the Fogera Plain in Ethiopia. More specifically, we want to investigate whether farmers reporting higher degrees of rice specialisation are also experiencing higher levels of rice commercialisation. We propose to analyse the relationship between rice specialisation and commercialisation with the following Equation (1):

Commercialization $_{i}=f\left(\right.$ Specialization $_{i}, \beta^{\prime} H_{\text {H_CHARACT }}$, $\gamma^{\prime} H H$ AGRIC_CHARACT, $\delta^{\prime}$ MKTNG_INFRASTR)

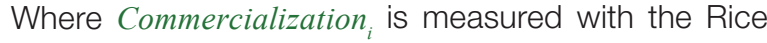
Commercialisation Index (RCl) and specifically:

$$
R C I_{i}=\left(\frac{\text { total value sales }_{i}}{\text { total value production }{ }_{i}^{9}}\right)
$$

The $\mathrm{RCl}$ of the farmers is calculated as a ratio of the rice sales over the total value of rice production. To calculate the total value of production, we calculate the average

8 The data that support the findings of this study are available from the corresponding author upon reasonable request.

$9 \quad$ Including stock. 
Table 3.1 List of variables included in the vectors

\begin{tabular}{|l|l|l|}
\hline Household characteristics & Household agricultural characteristics & Marketing infrastructure \\
\hline$\beta^{\prime}$ & $y^{\prime}$ & $\delta^{\prime}$ \\
\hline Age of household head & Total land size (ha) & Access to extension services \\
\hline Female head of the household & Farming experience in rice of the household head & Member of a cooperative \\
\hline Household size & Total labour (number of hired and family persons) & \\
\hline $\begin{array}{l}\text { Max. years of education in the } \\
\text { household }\end{array}$ & Access to irrigation & \\
\hline Normalised Asset Index & Having cash crops ${ }^{11}$ & \\
\hline MPl'12 & Rice land productivity & \\
\hline & Market distance & \\
\hline
\end{tabular}

Source: Author's own, using data from an APRA Rice farmers' survey (2018)

price of rice sale of each household and we multiply it with the total quantity produced, including the stock of rice in store (rice held from the previous production season)..$^{10}$ Specialization $_{i}$ is measured as the share of land cultivated with rice over the total land cultivated and non-cultivated throughout the year.

Underpinning our estimation strategy is the assumption that, due to the push for rice farming in the Fogera Plain, as farmers move into rice cultivation, they will increasingly commercialise given the increasing demand for rice as a cash crop. Table 3.1 presents the variables included in the vectors of Equations (1).

Looking at the independent variables in Equations (1), $\beta^{\prime}$ is a vector containing household characteristics; $\gamma^{\prime}$ is a vector containing variables on household characteristics relative to the agricultural activity, $\delta^{\prime}$ contains information on the marketing infrastructure and, finally, $v_{i}$ are the district fixed effects.

One of the main variables of interest in this analysis is related to farmers' landownership, where we expect small landowners to demonstrate a high degree of specialisation given the policy push in Fogera to adopt rice and in accordance with what is seen in the literature. Among the control variables, $\beta^{\prime}$, we include household characteristics such as, gender, age group, household size, education of the household head among others, likely to have a role in the determination of preferences about income and product orientation.
Other factors likely to play a crucial role in shaping farmers' decision on commercialisation are related to household resource endowment, $\gamma^{\prime}$, in terms of land, labour and assets, but also distance to market (measured in number of minutes by foot) and rice land productivity, measured as the share of total value of rice production over the total area of land cultivated with rice. ${ }^{13}$ While, marketing infrastructures such as access to extension services and being member of a cooperative, $\delta^{\prime}$, are all likely to influence farmers' access to markets.

Due to the cross-sectional nature of our dataset, any type of estimation strategy accounting for the possible endogeneity in the relationship between specialisation and commercialisation would inevitably be limited by the missing time dimension in our collected data. Nevertheless, we believe that our findings provide useful insights about the relationship between poverty (as proxied by farm size), rice specialisation and commercial orientation of smallholders. These insights allow us to propose policy initiatives, particularly for poorer rice farmers constrained by land size.

10 The median price per district have been assigned to those farmers reporting price per $\mathrm{kg}>20$ Ethiopian Birr.

11 Cash crops include the following crops: teff, Irish potato, onion, garlic, pepper, tomato, other vegetables. For the list of all crops, please refer to Table A1 in the Appendix.

12 The Multidimensional Poverty Index (MPI) is used to account for the extent of deprivation across health, education and living standards.

13 Rice land productivity is defined as: (total value production of rice/total area cultivated with rice)/100,000 


\section{RESULTS AND ANALYSIS}

\subsection{Land size, specialisation and poverty}

In this section we begin by presenting key farm household characteristics, by district. To facilitate presentation the information is split into household and agricultural characteristics and presented by farm size categories, created by splitting the sample in three quantiles - see Table 4.1.14
As reported in Table 4.1, the larger the land holding the higher the wealth indicators of the households - lower multidimensional poverty indicator, higher asset indexes. In terms of household characteristics, we observe that households with greater amount of land have, on average, older household heads, are more likely to be male headed and literate, while we do not observe substantial differences in terms of household size and years of education of the head of the household. In addition, large landowners are, on

Table 4.1 - Individual and household characteristics, by land size categories

\begin{tabular}{|c|c|c|c|c|}
\hline & Total sample & $\begin{array}{l}\text { Very small } \\
\text { landowners }\end{array}$ & $\begin{array}{l}\text { Small } \\
\text { landowners }\end{array}$ & $\begin{array}{l}\text { Larger } \\
\text { landowners }\end{array}$ \\
\hline Share land with rice & $\begin{array}{l}51.2 \% \\
(24.9 \%)\end{array}$ & $\begin{array}{l}61.5 \% \\
(25.9 \%)\end{array}$ & $\begin{array}{l}41.7 \% \\
(19.1 \%)\end{array}$ & $\begin{array}{l}36.2 \% \\
(13.9 \%)\end{array}$ \\
\hline Total land - cultivated and non-cultivated (ha) & $\begin{array}{l}1.65 \\
(0.93) \\
\end{array}$ & $\begin{array}{l}0.98 \\
(0.36)\end{array}$ & $\begin{array}{l}1.92 \\
(0.22)\end{array}$ & $\begin{array}{l}3.06 \\
(0.70)\end{array}$ \\
\hline $\mathrm{RCl}$ & $\begin{array}{l}31.0 \\
(20.0)\end{array}$ & $\begin{array}{l}29.8 \\
(20.4)\end{array}$ & $\begin{array}{l}33.2 \\
(20.3)\end{array}$ & $\begin{array}{l}31.5 \\
(18.3)\end{array}$ \\
\hline Normalised Asset Index & $\begin{array}{l}0.40 \\
(0.18)\end{array}$ & $\begin{array}{l}0.33 \\
(0.16)\end{array}$ & $\begin{array}{l}0.43 \\
(0.17)\end{array}$ & $\begin{array}{l}0.54 \\
(0.17) \\
\end{array}$ \\
\hline MPI & $\begin{array}{l}38.5 \\
(15.0)\end{array}$ & $\begin{array}{l}39.1 \\
(15.4)\end{array}$ & $\begin{array}{l}39.1 \\
(15.2)\end{array}$ & $\begin{array}{l}36.2 \\
(13.4)\end{array}$ \\
\hline Age of the household head & $\begin{array}{l}44.1 \\
(12.3)\end{array}$ & $\begin{array}{l}42.8 \\
(13.0)\end{array}$ & $\begin{array}{l}44.3 \\
(12.1)\end{array}$ & $\begin{array}{l}47.4 \\
(9.8) \\
\end{array}$ \\
\hline Household size & $\begin{array}{l}5.5 \\
(2.0)\end{array}$ & $\begin{array}{l}5.0 \\
(2.0)\end{array}$ & $\begin{array}{l}5.7 \\
(2.0)\end{array}$ & $\begin{array}{l}6.4 \\
(1.9)\end{array}$ \\
\hline Female head & $10.8 \%$ & $16.2 \%$ & $4.9 \%$ & $4.0 \%$ \\
\hline Head literate & $23.7 \%$ & $18.8 \%$ & $23.1 \%$ & $37.1 \%$ \\
\hline Years of schooling of household head (if >0) & $\begin{array}{l}5.8 \\
(3.7)\end{array}$ & $\begin{array}{l}5.3 \\
(3.7) \\
\end{array}$ & $\begin{array}{l}6.0 \\
(3.9) \\
\end{array}$ & \begin{tabular}{|l|}
7.1 \\
$(3.2)$ \\
\end{tabular} \\
\hline Has any member had off-farm/non-farm work? & $22.0 \%$ & $23.1 \%$ & $21.4 \%$ & $19.9 \%$ \\
\hline Access to electricity & $7.5 \%$ & $7.2 \%$ & $8.2 \%$ & $7.3 \%$ \\
\hline Access to drinking water & $56.0 \%$ & $55.3 \%$ & $52.7 \%$ & $61.6 \%$ \\
\hline Access to sanitation & $44.6 \%$ & $62.2 \%$ & $49.5 \%$ & $45.0 \%$ \\
\hline School going age child not in education & $38.7 \%$ & $36.2 \%$ & $46.2 \%$ & $36.0 \%$ \\
\hline$N$ & 722 & 389 & 182 & 151 \\
\hline
\end{tabular}

Note: Standard deviations in parentheses

Source: Authors' own, using data from APRA rice farmers' survey (2018)

14 While we refer to differences between small, medium and large farms, the majority of these farms would be considered small-scale by most accounts. In other words, we are describing the distributional range within the smallholder category. 
average, less likely to participate in non-farm or off-farm activities while small landowners report a lower level of access to health services and, interestingly, a lower level of schooling-age children out of the education system.

Importantly, for this paper, the descriptive statistics indicate that while smallholder farmers report a lower level of rice commercialisation, medium and larger landowners are reporting similar levels of $\mathrm{RCl}$. Looking at the level of specialisation, we observe an inverse relationship with land size, with small landowners having, on average, more than two-thirds of the land cultivated with rice while large landowners report having less than one-third of the land. Figure 4.1, shows evidence of non-linearity in the relationship between land ownership and rice specialisation.

The simple scatter plot of share of land cultivated to rice and total land shows a clear negative relationship. The quadratic prediction function in Figure 2.1 shows evidence of a possible quadratic relationship between land ownership and rice specialisation, with a minimum of the function in correspondence of, roughly, 3.7ha of total land. In other words, at low farm sizes, farmers dedicate proportionally more of their land to rice production, indicating that they are more specialised. As farm size increases, farmers dedicate a lower share of land to rice up to a point, after which at large land holdings (over approx. 4ha) farmers increase the share of rice cultivated. The likely explanation for this is that lower farm sizes proxy for poorer households and, as such, rice constitutes the staple food consumption crop. This means there is a minimum efficient land size to grow a sufficient amount of rice to ensure food security. This explains why small landholders have to dedicate such a large proportion of their land to rice. As rice is a staple, fast growing crop, smallholders use rice as a means of food consumption/food security.

\subsection{Determinants of rice commercialisation: a story about specialisation?}

We begin this section by proposing four categories based on the extent of rice commercialisation of the farmers, and specifically: i) Low rice commercialisation: share of rice sold between 0 per cent and 25 per cent; ii) Moderately low rice commercialisation: share of rice sold between 26 per cent and 50 per cent; iii) Moderately high rice commercialisation: share of rice sold between 51 per cent and 75 per cent and; iv) High rice commercialisation: share of rice sold between 76 per cent and 100 per cent. Using these rice commercialisation categories, we present the household and agricultural characteristics in Table 4.2.

From the results in Table 4.2, we observe an inverse relationship between commercialisation and specialisation, with highly commercialised farmers reporting the lowest level of rice specialisation (on average, 32.6 per cent of land is cultivated with rice

\section{Figure 4.1 - Relationship between land ownership and rice specialisation}

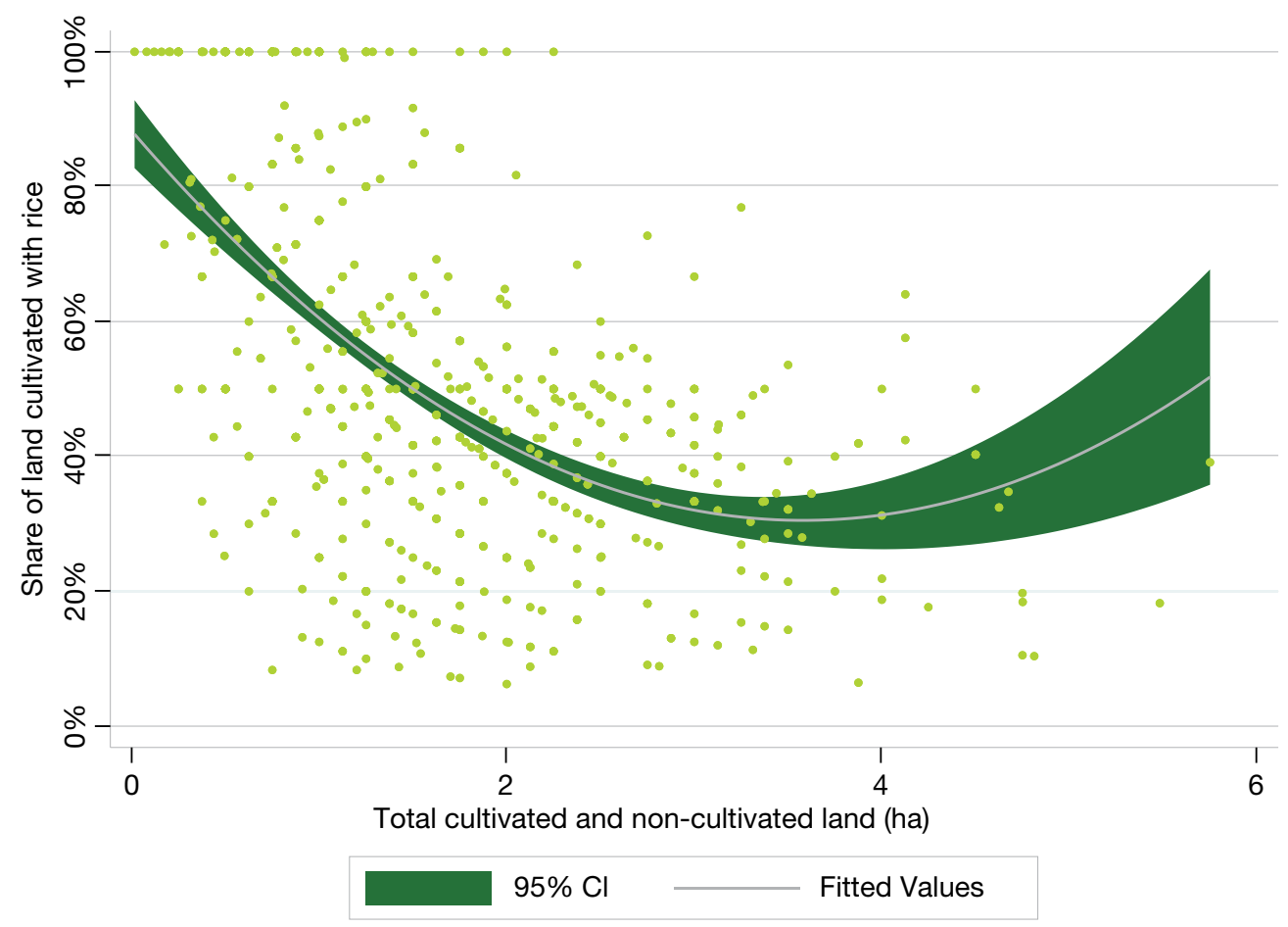

Source: Authors' own, using data from APRA rice farmers' survey (2018) 
as compared to 53 per cent of those who are low commercialisers). We also observe that a much greater proportion of highly commercialised farmers cultivate cash crops (61.5 per cent), contrary to the other categories where only one-third of the households grow cash crops. Half of all households have access to irrigation, with highly commercialised farmers reporting the highest share of access, equal to 61 per cent. They also have higher access to extension services and report the lowest share of cooperative members.
Looking at the possible relationship of the $\mathrm{RCl}$ with rice specialisation and land ownership, Figure 4.2 presents the quadratic prediction function for the total sample.

We observe an opposite relationship of rice specialisation and land ownership with rice commercialisation. While the former indicator presents a decreasing relationship with rice commercialisation, with a possible absence of relationship for highly specialised farmers, the latter indicator shows an increasing level of rice commercialisation with higher

Table 4.2 - Household and agricultural characteristics, by rice commercialisation category

\begin{tabular}{|c|c|c|c|c|c|c|}
\hline & Total sample & $\begin{array}{l}\text { Low } \\
\text { commercial }\end{array}$ & $\begin{array}{l}\text { Moderately } \\
\text { low } \\
\text { commercial }\end{array}$ & $\begin{array}{l}\text { Moderately } \\
\text { high } \\
\text { commercial }\end{array}$ & $\begin{array}{l}\text { High } \\
\text { commercial }\end{array}$ & P-value \\
\hline $\mathrm{RCl}$ & $\begin{array}{l}31.0 \\
(20.0)\end{array}$ & $\begin{array}{l}13.2 \\
(8.9)\end{array}$ & $\begin{array}{l}36.7 \\
(7.2)\end{array}$ & $\begin{array}{l}59.9 \\
(6.1)\end{array}$ & $\begin{array}{l}86.1 \\
(7.0)\end{array}$ & 0.000 \\
\hline Share land with rice & $\begin{array}{l}51.2 \% \\
(24.9 \%)\end{array}$ & $\begin{array}{l}53.0 \% \\
(24.8 \%)\end{array}$ & $\begin{array}{l}51.5 \% \\
(24.8 \%)\end{array}$ & $\begin{array}{l}49.0 \% \\
(22.5 \%)\end{array}$ & $\begin{array}{l}32.6 \% \\
(25.4 \%)\end{array}$ & 0.001 \\
\hline $\begin{array}{l}\text { Total land - } \\
\text { cultivated plus } \\
\text { non-cultivated }\end{array}$ & $\begin{array}{l}1.65 \\
(0.93)\end{array}$ & $\begin{array}{l}1.57 \\
(0.89)\end{array}$ & $\begin{array}{l}1.68 \\
(0.94)\end{array}$ & $\begin{array}{l}1.86 \\
(1.06)\end{array}$ & $\begin{array}{l}1.62 \\
(0.85)\end{array}$ & 0.118 \\
\hline $\begin{array}{l}\text { Age of the } \\
\text { household head }\end{array}$ & $\begin{array}{l}44.1 \\
(12.3)\end{array}$ & $\begin{array}{l}45.8 \\
(12.8)\end{array}$ & $\begin{array}{l}42.5 \\
(11.0)\end{array}$ & $\begin{array}{l}42.9 \\
(13.1)\end{array}$ & $\begin{array}{l}48.1 \\
(15.2)\end{array}$ & 0.002 \\
\hline Household size & $\begin{array}{l}5.5 \\
(2.0)\end{array}$ & $\begin{array}{l}5.6 \\
(2.1)\end{array}$ & $\begin{array}{l}5.5 \\
(2.0)\end{array}$ & $\begin{array}{l}5.6 \\
(2.3)\end{array}$ & $\begin{array}{l}4.7 \\
(1.8)\end{array}$ & 0.200 \\
\hline Female head & $10.8 \%$ & $11.3 \%$ & $12.3 \%$ & $2.8 \%$ & $7.7 \%$ & 0.121 \\
\hline $\begin{array}{l}\text { Max years of } \\
\text { schooling of } \\
\text { household head }\end{array}$ & $\begin{array}{l}5.8 \\
(3.7)\end{array}$ & $\begin{array}{l}6.2 \\
(3.8)\end{array}$ & $\begin{array}{l}5.6 \\
(3.5)\end{array}$ & $\begin{array}{l}5.6 \\
(4.0)\end{array}$ & $\begin{array}{l}5.0 \\
(4.4)\end{array}$ & 0.119 \\
\hline $\begin{array}{l}\text { Farming experience } \\
\text { rice (years) }\end{array}$ & $\begin{array}{l}12.3 \\
(6.4) \\
\end{array}$ & $\begin{array}{l}12.5 \\
(6.3)\end{array}$ & $\begin{array}{l}12.3 \\
(6.5) \\
\end{array}$ & $\begin{array}{l}12.3 \\
(6.7) \\
\end{array}$ & $\begin{array}{l}9.8 \\
(6.1)\end{array}$ & 0.241 \\
\hline $\begin{array}{l}\text { Normalised Asset } \\
\text { Index }\end{array}$ & $\begin{array}{l}0.398 \\
(0.183)\end{array}$ & $\begin{array}{l}0.388 \\
(0.181) \\
\end{array}$ & $\begin{array}{l}0.400 \\
(0.182) \\
\end{array}$ & $\begin{array}{l}0.419 \\
(0.194) \\
\end{array}$ & $\begin{array}{l}0.421 \\
(0.184) \\
\end{array}$ & 0.527 \\
\hline Total hired labour & $\begin{array}{l}9.7 \\
(24.1) \\
\end{array}$ & $\begin{array}{l}9.8 \\
(30.3)\end{array}$ & $\begin{array}{l}9.2 \\
(18.3) \\
\end{array}$ & $\begin{array}{l}11.7 \\
(13.5)\end{array}$ & $\begin{array}{l}10.3 \\
(30.9)\end{array}$ & 20.884 \\
\hline Total family labour & $\begin{array}{l}22.4 \\
(17.7)\end{array}$ & $\begin{array}{l}22.3 \\
(16.6)\end{array}$ & $\begin{array}{l}23.0 \\
(18.2)\end{array}$ & $\begin{array}{l}21.8 \\
(15.6)\end{array}$ & $\begin{array}{l}16.9 \\
(27.3) \\
\end{array}$ & 0.390 \\
\hline $\begin{array}{l}\text { Farmers growing } \\
\text { cash crops }\end{array}$ & $38.2 \%$ & $38.7 \%$ & $36.6 \%$ & $35.2 \%$ & $61.5 \%$ & 0.084 \\
\hline Access to irrigation & $54.2 \%$ & $47.7 \%$ & $58.5 \%$ & $59.2 \%$ & $61.5 \%$ & 0.032 \\
\hline $\begin{array}{l}\text { Distance from } \\
\text { market (minutes) }\end{array}$ & $\begin{array}{l}86.3 \\
(71.9)\end{array}$ & $\begin{array}{l}80.4 \\
(68.9)\end{array}$ & $\begin{array}{l}89.7 \\
(70.1)\end{array}$ & $\begin{array}{l}82.6 \\
(74.8)\end{array}$ & $\begin{array}{l}120.8 \\
(104.7)\end{array}$ & 0.031 \\
\hline $\begin{array}{l}\text { Rice land } \\
\text { productivity }\end{array}$ & $\begin{array}{l}0.502 \\
(0.310)\end{array}$ & $\begin{array}{l}0.494 \\
(0.366)\end{array}$ & $\begin{array}{l}0.509 \\
(0.267)\end{array}$ & $\begin{array}{l}0.478 \\
(0.205)\end{array}$ & $\begin{array}{l}0.557 \\
(0.352)\end{array}$ & 0.660 \\
\hline $\begin{array}{l}\text { Access to } \\
\text { extension service }\end{array}$ & $74.1 \%$ & $72.7 \%$ & $75.3 \%$ & $70.4 \%$ & $84.6 \%$ & 0.465 \\
\hline $\begin{array}{l}\text { Member of a } \\
\text { cooperative }\end{array}$ & $47.4 \%$ & $52.2 \%$ & $43.3 \%$ & $50.7 \%$ & $34.6 \%$ & 0.076 \\
\hline$N$ & 722 & 300 & 325 & 71 & 26 & \\
\hline
\end{tabular}

Note: Standard deviations in parentheses

Source: Authors' own, using data from APRA rice farmers' survey (2018) 
Figure 4.2 - Relationship between RCl, rice specialisation and land ownership

\section{Total Sample}

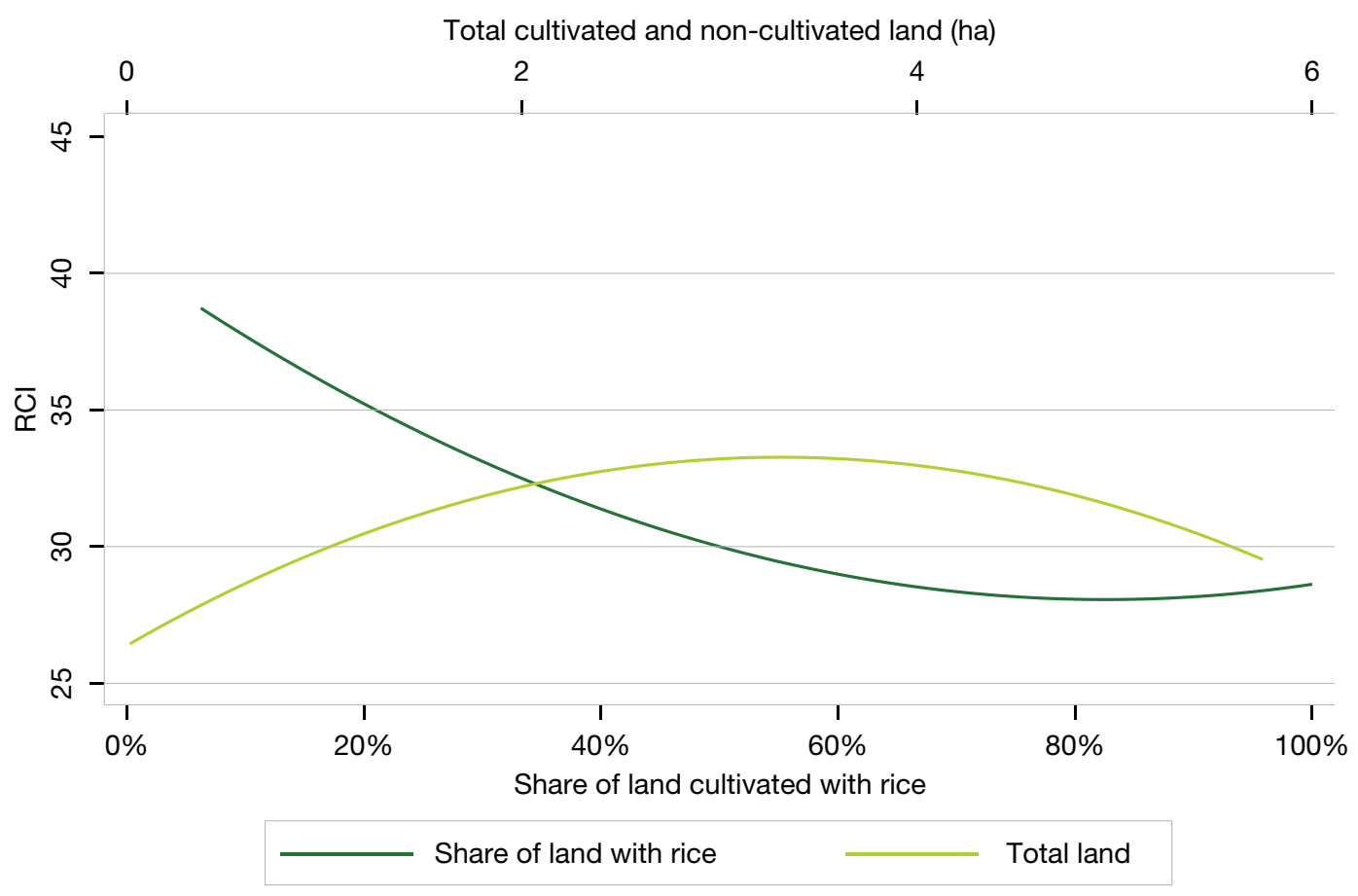

Source: Authors' own, using data from APRA rice farmers' survey (2018)

amounts of land, with a possible inverse U-shaped relationship. This appears to confirm the hypothesis that the larger and wealthier landowners are producing rice for the market and for profit, while the smaller and poorer farmers are producing largely for food security purposes. At the same time, we observe that farmers with the lowest level of rice specialisation are those reporting the highest levels of rice commercialisation, while we do not observe large differences in terms of commercialisation between mid-specialised and highly specialised farmers.

Investigating in more detail factors related to rice commercialisation, Table 4.3 presents the results of the ordinary least squares (OLS) model, as presented in Equation (1). ${ }^{15}$

Results for the whole sample in Column 1 above show no relationship between rice commercialisation and specialisation and confirm a strong reverse $\mathrm{U}$-shaped relationship between land ownership and rice commercialisation. Findings are confirmed for small and medium landowners in Columns 2 and 3, whereas this relationship is not observed for large landowners.

Among the other significant determinants of rice commercialisation, we find that the age of the household head, access to irrigation, distance from market and the rice land productivity, are all positively associated with commercialisation, while only the coefficient relative to the maximum years of education of the household head reports a negative sign. For small landowners, distance from the market and rice land productivity report a positive sign, while for medium landowners we observe that access to irrigation is positively related with commercialisation while rice land productivity is negatively correlated. Finally, for large landowners we find that female headed households are more likely to have higher levels of commercialisation.

Results in Columns 5-8 are instead presented by rice commercialisation category, as introduced earlier. Findings confirm an inverse $U$-shaped relationship between rice commercialisation and land ownership (except for the highly commercialised farmers) but also highlight the positive and significant correlation between rice specialisation and commercialisation for the farmers in the mid-categories of rice commercialisation.

15 For a more complete set of results for the total sample, please refer to Table A2 in the Appendix 
Table 4.3 - OLS results - rice commercialisation

\begin{tabular}{|c|c|c|c|c|c|c|c|c|}
\hline & All & $\begin{array}{l}\text { Very small } \\
\text { landowners }\end{array}$ & \begin{tabular}{|l} 
small \\
landowners
\end{tabular} & \begin{tabular}{|l|} 
Larger \\
landowners
\end{tabular} & $\begin{array}{l}\text { Low } \\
\text { commercial }\end{array}$ & \begin{tabular}{|l|} 
Moderately \\
low \\
commercial \\
\end{tabular} & $\begin{array}{l}\text { Moderately } \\
\text { high } \\
\text { commercial }\end{array}$ & \begin{tabular}{|l} 
High \\
commercial
\end{tabular} \\
\hline & 1 & 2 & 3 & 4 & 5 & 6 & 7 & 8 \\
\hline Specialisation & $\begin{array}{l}0.003 \\
(0.043)\end{array}$ & $\begin{array}{l}-0.003 \\
(0.057)\end{array}$ & $\begin{array}{l}-0.148 \\
(0.109)\end{array}$ & $\begin{array}{l}-0.016 \\
(0.167)\end{array}$ & $\begin{array}{l}0.001 \\
(0.028)\end{array}$ & $\begin{array}{l}0.138^{\star \star \star} \\
(0.027) \\
\end{array}$ & $\begin{array}{l}0.209^{\star \star} \\
(0.092)\end{array}$ & $\begin{array}{l}0.140 \\
(0.179)\end{array}$ \\
\hline $\begin{array}{l}\text { Total land size } \\
\text { (ha) }\end{array}$ & $\begin{array}{l}0.109^{\star \star \star} \\
(0.033)\end{array}$ & $\begin{array}{l}0.451^{\star \star \star} \\
(0.112)\end{array}$ & $\begin{array}{l}0.672^{\star \star \star} \\
(0.150)\end{array}$ & $\begin{array}{l}0.112 \\
(0.093)\end{array}$ & $\begin{array}{l}0.087^{\star \star \star} \\
(0.021)\end{array}$ & $\begin{array}{l}0.116^{\star \star \star} \\
(0.020)\end{array}$ & $\begin{array}{l}0.099^{\star} \\
(0.050)\end{array}$ & $\begin{array}{l}-0.005 \\
(0.025)\end{array}$ \\
\hline $\begin{array}{l}\text { Total land size } \\
\text { (ha) }^{2}\end{array}$ & \begin{tabular}{|l}
$-0.021^{\star \star \star}$ \\
$(0.007)$
\end{tabular} & \begin{tabular}{|l}
$-0.188^{\star \star \star}$ \\
$(0.064)$
\end{tabular} & $\begin{array}{l}-0.210^{\star \star \star} \\
(0.050)\end{array}$ & $\begin{array}{l}-0.012 \\
(0.013)\end{array}$ & $\begin{array}{l}-0.021^{\star \star \star} \\
(0.004)\end{array}$ & $\begin{array}{l}-0.021^{\star \star \star} \\
(0.004)\end{array}$ & \begin{tabular}{|l}
$-0.017^{\star \star \star}$ \\
$(0.006)$
\end{tabular} & $\begin{array}{l}0.409 \\
(0.261)\end{array}$ \\
\hline \multicolumn{9}{|l|}{ Control Variables } \\
\hline $\begin{array}{l}\text { Age of the } \\
\text { household head }\end{array}$ & $\begin{array}{l}0.001^{* *} \\
(0.001)\end{array}$ & $\begin{array}{l}0.000 \\
(0.001)\end{array}$ & \begin{tabular}{|l}
-0.000 \\
$(0.001)$
\end{tabular} & $\begin{array}{l}-0.001 \\
(0.002)\end{array}$ & $\begin{array}{l}0.001^{\star *} \\
(0.001)\end{array}$ & $\begin{array}{l}0.001^{\star \star \star} \\
(0.000)\end{array}$ & $\begin{array}{l}0.002^{\star \star \star} \\
(0.000)\end{array}$ & $\begin{array}{l}-0.002 \\
(0.003)\end{array}$ \\
\hline Household size & $\begin{array}{l}0.002 \\
(0.005)\end{array}$ & $\begin{array}{l}0.000 \\
(0.008)\end{array}$ & $\begin{array}{l}-0.003 \\
(0.008)\end{array}$ & $\begin{array}{l}-0.005 \\
(0.011)\end{array}$ & $\begin{array}{l}0.002 \\
(0.005)\end{array}$ & $\begin{array}{l}0.008^{\star \star \star} \\
(0.003)\end{array}$ & $\begin{array}{l}0.005^{\star} \\
(0.003)\end{array}$ & $\begin{array}{l}0.039 \\
(0.032)\end{array}$ \\
\hline Female head & \begin{tabular}{|l|}
0.014 \\
$(0.025)$
\end{tabular} & $\begin{array}{l}-0.025 \\
(0.031)\end{array}$ & $\begin{array}{l}-0.043 \\
(0.050)\end{array}$ & $\begin{array}{l}0.142^{*} \\
(0.080)\end{array}$ & $\begin{array}{l}0.014 \\
(0.025)\end{array}$ & $\begin{array}{l}-0.007 \\
0.017)\end{array}$ & $\begin{array}{l}0.052^{\star \star \star} \\
(0.017)\end{array}$ & $\begin{array}{l}0.353^{*} \\
(0.175)\end{array}$ \\
\hline $\begin{array}{l}\text { Max education } \\
\text { level of household } \\
\text { (years) }\end{array}$ & $\begin{array}{l}-0.005^{*} \\
(0.002)\end{array}$ & $\begin{array}{l}-0.003 \\
(0.003)\end{array}$ & $\begin{array}{l}-0.006 \\
(0.005)\end{array}$ & $\begin{array}{l}0.003 \\
(0.006)\end{array}$ & $\begin{array}{l}-0.005^{*} \\
(0.002)\end{array}$ & $\begin{array}{l}-0.003^{\star \star} \\
(0.001)\end{array}$ & $\begin{array}{l}-0.003^{*} \\
(0.001)\end{array}$ & \begin{tabular}{|l}
$-0.048^{\star \star}$ \\
$(0.016)$
\end{tabular} \\
\hline $\mathrm{MPI}$ & $\begin{array}{l}0.001 \\
(0.001)\end{array}$ & $\begin{array}{l}0.001 \\
(0.001)\end{array}$ & $\begin{array}{l}-0.000 \\
(0.001)\end{array}$ & $\begin{array}{l}0.001 \\
(0.001)\end{array}$ & $\begin{array}{l}0.001 \\
(0.001)\end{array}$ & $\begin{array}{l}-0.000 \\
(0.000)\end{array}$ & $\begin{array}{l}0.001^{\star \star} \\
(0.000)\end{array}$ & $\begin{array}{l}0.013^{\star \star} \\
(0.004)\end{array}$ \\
\hline $\begin{array}{l}\text { Farming experience } \\
\text { of rice head (years) }\end{array}$ & $\begin{array}{l}-0.002 \\
(0.001)\end{array}$ & $\begin{array}{l}0.001 \\
(0.002)\end{array}$ & $\begin{array}{l}-0.006^{\star \star} \\
(0.003)\end{array}$ & $\begin{array}{l}0.000 \\
(0.002)\end{array}$ & $\begin{array}{l}-0.002 \\
(0.001)\end{array}$ & $\begin{array}{l}-0.001 \\
(0.001)\end{array}$ & $\begin{array}{l}-0.001^{*} \\
(0.001)\end{array}$ & $\begin{array}{l}0.008 \\
(0.011)\end{array}$ \\
\hline Total labour & $\begin{array}{l}0.003 \\
(0.013)\end{array}$ & $\begin{array}{l}-0.010 \\
(0.018)\end{array}$ & $\begin{array}{l}-0.001 \\
(0.021)\end{array}$ & $\begin{array}{l}-0.014 \\
(0.037)\end{array}$ & $\begin{array}{l}0.003 \\
(0.013)\end{array}$ & $\begin{array}{l}0.007 \\
(0.008)\end{array}$ & $\begin{array}{l}-0.004 \\
(0.008)\end{array}$ & $\begin{array}{l}-0.062 \\
(0.039)\end{array}$ \\
\hline Asset Index & \begin{tabular}{|l|}
0.026 \\
$(0.056)$
\end{tabular} & $\begin{array}{l}-0.084 \\
(0.084)\end{array}$ & $\begin{array}{l}0.183^{*} \\
(0.101)\end{array}$ & $\begin{array}{l}0.153 \\
(0.142)\end{array}$ & $\begin{array}{l}0.026 \\
(0.056)\end{array}$ & $\begin{array}{l}-0.056 \\
(0.034)\end{array}$ & $\begin{array}{l}-0.014 \\
(0.037)\end{array}$ & $\begin{array}{l}-0.187 \\
(0.269)\end{array}$ \\
\hline $\begin{array}{l}\text { Growing cash } \\
\text { crops }\end{array}$ & $\begin{array}{l}-0.026 \\
(0.021)\end{array}$ & $\begin{array}{l}-0.023 \\
(0.032)\end{array}$ & $\begin{array}{l}-0.023 \\
(0.038)\end{array}$ & $\begin{array}{l}-0.048 \\
(0.041)\end{array}$ & $\begin{array}{l}-0.026 \\
(0.021)\end{array}$ & $\begin{array}{l}0.003 \\
(0.014)\end{array}$ & $\begin{array}{l}0.002 \\
(0.013)\end{array}$ & $\begin{array}{l}-0.095 \\
(0.110)\end{array}$ \\
\hline Access to irrigation & $\begin{array}{l}0.033^{*} \\
(0.017)\end{array}$ & $\begin{array}{l}0.016 \\
(0.024)\end{array}$ & $\begin{array}{l}0.069^{\star \star} \\
(0.035)\end{array}$ & $\begin{array}{l}-0.025 \\
(0.037)\end{array}$ & $\begin{array}{l}0.033^{*} \\
(0.017)\end{array}$ & $\begin{array}{l}-0.029^{\star \star} \\
(0.012)\end{array}$ & $\begin{array}{l}0.014 \\
(0.011)\end{array}$ & $\begin{array}{l}0.038 \\
(0.075)\end{array}$ \\
\hline Extension service & $\begin{array}{l}0.021 \\
(0.019)\end{array}$ & $\begin{array}{l}0.028 \\
(0.023)\end{array}$ & $\begin{array}{l}-0.016 \\
(0.034)\end{array}$ & $\begin{array}{l}0.009 \\
(0.053)\end{array}$ & $\begin{array}{l}0.021 \\
(0.019)\end{array}$ & $\begin{array}{l}0.008 \\
(0.012)\end{array}$ & $\begin{array}{l}0.016 \\
(0.012)\end{array}$ & $\begin{array}{l}0.189^{\star} \\
(0.097)\end{array}$ \\
\hline $\begin{array}{l}\text { Member } \\
\text { cooperative }\end{array}$ & $\begin{array}{l}-0.010 \\
(0.017)\end{array}$ & $\begin{array}{l}-0.008 \\
(0.022)\end{array}$ & $\begin{array}{l}0.009 \\
(0.034)\end{array}$ & $\begin{array}{l}-0.027 \\
(0.037)\end{array}$ & $\begin{array}{l}-0.010 \\
(0.017)\end{array}$ & $\begin{array}{l}0.021^{\star \star} \\
(0.010)\end{array}$ & $\begin{array}{l}0.009 \\
(0.010)\end{array}$ & $\begin{array}{l}0.117 \\
(0.072)\end{array}$ \\
\hline $\begin{array}{l}\text { Distance from } \\
\text { market (in minutes) }\end{array}$ & $\begin{array}{l}0.020^{\star \star \star} \\
(0.006)\end{array}$ & $\begin{array}{l}0.013^{\star} \\
(0.007)\end{array}$ & $\begin{array}{l}0.010 \\
(0.013)\end{array}$ & $\begin{array}{l}0.018 \\
(0.015)\end{array}$ & $\begin{array}{l}0.020^{\star \star \star} \\
(0.006)\end{array}$ & $\begin{array}{l}0.000 \\
(0.003)\end{array}$ & $\begin{array}{l}0.010^{\star \star} \\
(0.004)\end{array}$ & $\begin{array}{l}-0.007 \\
(0.025)\end{array}$ \\
\hline $\begin{array}{l}\text { Rice land } \\
\text { productivity }\end{array}$ & $\begin{array}{l}0.057^{\star \star} \\
(0.027)\end{array}$ & $\begin{array}{l}0.075^{\star \star} \\
(0.033)\end{array}$ & $\begin{array}{l}-0.168^{\star \star \star} \\
(0.059)\end{array}$ & $\begin{array}{l}0.101 \\
(0.085)\end{array}$ & $\begin{array}{l}0.057^{\star \star} \\
(0.027)\end{array}$ & $\begin{array}{l}0.024^{\star \star} \\
(0.010)\end{array}$ & $\begin{array}{l}0.044^{\star \star \star} \\
(0.015)\end{array}$ & $\begin{array}{l}0.266 \\
(0.144)\end{array}$ \\
\hline Libokemkem & $\begin{array}{l}-0.012 \\
(0.017)\end{array}$ & $\begin{array}{l}-0.056^{\star \star} \\
(0.023)\end{array}$ & $\begin{array}{l}0.054 \\
(0.035)\end{array}$ & $\begin{array}{l}-0.015 \\
(0.032)\end{array}$ & $\begin{array}{l}-0.012 \\
(0.017)\end{array}$ & $\begin{array}{l}0.014 \\
(0.013)\end{array}$ & $\begin{array}{l}-0.001 \\
(0.012)\end{array}$ & $\begin{array}{l}-0.177 \\
(0.205)\end{array}$ \\
\hline Dera & $\begin{array}{l}0.019 \\
(0.037)\end{array}$ & $\begin{array}{l}0.051 \\
(0.053)\end{array}$ & $\begin{array}{l}0.003 \\
(0.056)\end{array}$ & $\begin{array}{l}-0.064 \\
(0.073)\end{array}$ & $\begin{array}{l}0.019 \\
(0.037)\end{array}$ & $\begin{array}{l}0.033 \\
(0.020)\end{array}$ & $\begin{array}{l}0.017 \\
(0.019)\end{array}$ & $\begin{array}{l}-0.036 \\
(0.102)\end{array}$ \\
\hline $\begin{array}{l}\text { Observations } \\
\text { R-squared }\end{array}$ & $\begin{array}{l}717 \\
0.707\end{array}$ & $\begin{array}{l}385 \\
0.700\end{array}$ & $\begin{array}{l}182 \\
0.782\end{array}$ & $\begin{array}{l}150 \\
0.773\end{array}$ & $\begin{array}{l}298 \\
0.747\end{array}$ & $\begin{array}{l}323 \\
0.953\end{array}$ & $\begin{array}{l}70 \\
0.983\end{array}$ & $\begin{array}{l}26 \\
0.995\end{array}$ \\
\hline
\end{tabular}

Note: Robust standard errors in parentheses $-{ }^{* \star *} p<0.01,{ }^{* \star} p<0.05,{ }^{*} p<0.1$

Source: Authors' own, using data from APRA rice farmers' survey (2018) 
While it is well established that the introduction of rice into the Fogera Plain has solved what was a significant food insecurity problem, ${ }^{16}$ the promises associated with commercialisation are not equally on offer for all. Smaller farmers have not, on average, been able to reap the benefits from a market-oriented outlook. This is because their land sizes are only big enough to produce rice to fulfil home consumption needs, and not much more. This has much to do with the rice culture of the area and the recent historical change in food preferences and the substitution of rice for teff in the local diet. Observing poverty indicators for these households it is clear that they are, on average, significantly poorer across a range of indicators. Whereas we observe a negative relationship between the MPI and land size categories across the total sample, in terms of the $\mathrm{RCl}$ we observe that very small landowners (0-1ha) report lower levels of commercialisation compared to the other farmers. Furthermore, larger wealthier farmers have an advantage of crop diversification, likely due to the larger land size.

The recent historical policy emphasis on rice as a pathway out of poverty has not necessarily translated into positive outcomes for all households. This has implications for the nature of structural change in the area and the associated (in)equitable access to the gains from market-oriented commercialisation strategies. To enable those smaller/poorer farmers to move into market-oriented commercialisation pathways rather than consumption-oriented ones, the following targeted interventions are likely to be helpful.

First, rice intensification, which is production of rice at least twice per year with better use of inputs (seed, fertiliser, and other agro-chemicals), can be encouraged through the application of necessary agronomic practices and promotion of access to irrigation. This is because use of irrigation and application of fertiliser at the recommended rate resulted in increased productivity per unit area.
Second, encouragement of diversification into high value crops alongside rice, will allow smallholders to exploit market opportunities, for instance with irrigated vegetable production during the 'rice off-season'. The emerging trends indicate that rice farmers are diversifying into vegetable production by investing in irrigation facilities. So, it is not about moving out of rice production but complementing it with other high value crops (such as vegetables) to ensure the efficient utilisation of the available land resources through production along with maximising the benefit from better market access. Qualitative research (Assaye and Alemu, 2020) suggests that much of the benefit of complementary production goes to middlemen due to the limited marketing skills of smallholder farmers. Counteracting this so that smallholders can retain a higher proportion of the profits requires providing farmers with marketing skill and enhancing their bargaining power through group action (cooperatives) and improved market information system. In addition, training and awareness creation on the reduction in soilquality of pursuing rice as a monocrop will be helpful.

To ensure the sustainability of the observed livelihood improvements in the Fogera Plain, the issue of land size and access to land play a critical role. The current land market operates in the form of sharing and lease arrangements through informal land market information system. If the scarcest resource in the area (land) is to be used efficiently there has to be a formal land use transfer system where those who cannot properly manage due to shortage of labour or engagement in other non-farm businesses can ensure transfer to efficient users with ample labour and production experiences. The recent initiative in the Fogera Plain to redistribute communal land to landless youth households is not a permanent solution as the land available for redistribution is limited in size. Thus, it will be important, first, to strengthen the land marketing system to ensure the transfer of land from low to more efficient users given the huge range in paddy rice

16 As evidenced from the shift in status from a food aid dependent area to one that is food secure, where the public office for food security and emergency response is downscaled to only emergency response in the area. 
productivity levels achieved (3.2 to 95.0 qtls/ha and, second, to ensure the development of entrepreneurial skills for those with small farm size and landless farmers to ensure emergence of complementary farm service businesses like mechanisation, plant protection, postharvest and transport services.

Due to the increase in the number of landless households and increased tensions of land, in 2008 the local authorities started to distribute communal and grazing lands to landless households. Data gathered from the Fogera District Office indicates that approximately 1,600ha of land was distributed to about 2,950 youth landless households over the last ten years only in Fogera district, which is mainly used for rice production. Since land resources are limited, alternative measures are needed to ensure (i) intensification through improved technology use and access to irrigation and (ii) measures to reduce population pressure on the land, such as by facilitating the outflow of labour from agriculture to other economic sectors along with supporting the urbanisation process. It will also be critical to emphasise the role of education in enabling youth with limited access to land as a pathway into off-farm wage or business income. It simply is not realistic to expect that rural youth can continue to inherit or be allocated land with so little available in many smallholder farming areas. 
Alemu, D., Assaye, A., Tadesse, T., Tesfaye, A. and Thompson, J. (2018) Historical Analysis of Rice Commercialisation in Ethiopia: The Case of the Fogera Plain. APRA Working Paper 18. Brighton: Future Agricultures Consortium. Available at: https://opendocs.ids.ac.uk/opendocs/handle/20.500.12413/14283 (Accessed: 2 November 2021).

Alemu, D. and Berhanu, K. (2018) The Political Economy of Agricultural Commercialisation in Ethiopia: Discourses, Actors and Structural Impediments. APRA Working Paper 14. Brighton: Future Agricultures Consortium. Available at: https://opendocs.ids.ac.uk/opendocs/handle/20.500.12413/13952 (Accessed: 2 November 2021).

Anang, B.T., Bäckman, S. and Rezitis, A. (2016) 'Does farm size matter? Investigating scale efficiency of peasant rice farmers in northern Ghana', Economics Bulletin 36(4): 2275-2290.

Assaye, A. and Alemu, D. (2020) Enhancing Production of Quality Rice in Ethiopia: Dis/incentives for Rice Processors. APRA Brief 22. Brighton: Future Agricultures Consortium. Available at: https://opendocs.ids.ac.uk/ opendocs/handle/20.500.12413/16700 (Accessed: 2 November 2021).

Barrett, C.B. (2008) 'Smallholder market participation: concepts and evidence from eastern and southern Africa', Food Policy 33(4): 299-317.

Bellon, M.R., Kotu, B.H., Azzarri, C. and Caracciolo, F. (2020) 'To diversify or not to diversify, that is the question. Pursuing agricultural development for smallholder farmers in marginal areas of Ghana', World Development 125 (2020): 104682.

Cameron, A.C. and Trivedi, P.K. (2010) Microeconometrics Using Stata, Revised Edition. StataCorp LP.

Carter, M.R, and Barrett, C.B. (2006) 'The economics of poverty traps and persistent poverty: An asset-based approach', Journal of Development Studies 42(2): 178-199.

Chapoto, A., Mabiso, A. and Bonsu, A. (2013) Agricultural Commercialization, Land Expansion, and Homegrown Large-Scale Farmers: Insights from Ghana. IFPRI Discussion Paper 01286. Development Strategy and Governance Division. Washington, DC: International Food Policy Research Institute (IFPRI).

Chirwa, E., Sabates-Wheeler, R. and Saha, A. (2018) Agricultural Policy Research in Africa (APRA) Research Programme Consortium: Commercialisation, Women's Empowerment and Poverty Reduction. APRA Outcome Indicators Paper. Brighton: Future Agricultures Consortium. Available at: https://www.future-agricultures.org/wpcontent/uploads/2018/07/APRA-Outcome-Indicators-Paper.pdf (Accessed: 2 November 2021).

Collier, P. (2008) 'The Politics of Hunger: How Illusion and Greed Fan the Food Crisis', Foreign Affairs 87(6): 67-79.

Collier, P. and Dercon, S. (2009) African Agriculture in 50 Years: Smallholders in a Rapidly Changing World? Expert Meeting on How to Feed the World in 2050. Food and Agriculture Organization of the United Nations Economic and Social Development Department. Available at: http://ss.rrojasdatabank.info/ak983e00.pdf (Accessed: 2 November 2021).

CSA (Central Statistics Agency) (2018) Report on area and production of major crops (Private peasant holdings, Meher season). Agricultural sample survey 2017/18 (2010 E.C.). Statistical bulletin 586. Addis Ababa: CSA.

CSA (Central Statistics Agency) (2019) Report on area and production of major crops (Private peasant holdings, Meher season). Agricultural sample survey 2018/19 (2011 E.C.). Statistical bulletin 589. Addis Ababa: CSA.

Das, V.K. and Ganesh-Kumar, A. (2017) Drivers of farmers' income: The role of farm size and diversification. WP2017-013. Mumbai: Indira Gandhi Institute of Development Research. 
del Prete, D., Ghins, L., Magrini, E. and Pauw, K. (2018) Land consolidation, specialization and household diets: Evidence from Rwanda. IFPRI Discussion Paper 01728. Development Strategy and Governance Division. Washington, DC: International Food Policy Research Institute (IFPRI).

Djurfeldt, A.A., G. Djurfeldt, E. Hillbom, A.Isinika, M. Joshua, W. Kalindi, E. Msuya, W. Mulwafu, and M. Wamulume. (2019) 'Is There Such a Thing as Sustainable Agricultural Intensification in Smallholder-based Farming in SubSaharan Africa? Understanding Yield Differences in Relation to Gender in Malawi, Tanzania and Zambia', Development Studies Research 6(1): 62-75.

Evenson, R.E. and Gollin, D. (2003) 'Assessing the impact of the Green Revolution 1960 to 2000', Science 300(5620): 758-762.

Fan, S. and Chan-Kang, C. (2005) 'Is small beautiful? Farm size, productivity and poverty in Asian agriculture', in: D. Colman and N. Vink (eds.), Reshaping agriculture's contributions to society. Proceedings of the 55th International Conference of Agricultural economists Held on 16-22 August, 2003, Durban, South Africa.

Gebremedhin. B. and Jaleta, M. (2010) Commercialization of smallholders: Does market orientation translate into market participation? Improving Productivity and Market Success (IPMS) of Ethiopian farmers project. Working Paper 22. Nairobi: International Livestock Research Institute (ILRI).

Hardaker, J.B., Huirne, R.B.M. and Anderson, J.R. (1997) Coping with risk in agriculture. Wallingford: CAB International.

Isinika A., Mlay G., Boniface G., Mdoe N., Poulton C. and Saha A. (2020) Does Rice Commercialisation Impact on Livelihood? Experience from Mngeta in Kilombero District, Tanzania. Available at: https://opendocs.ids.ac.uk/ opendocs/handle/20.500.12413/15269 (Accessed: 2 November 2021).

Jaleta, M., Gebremedhin, B. and Hoekstra, D. (2009) Smallholder commercialization: Processes, determinants and impact. ILRI Discussion Paper 18. Nairobi: International Livestock Research Institute.

Li, L., Varua, M.E., Komarek, A.M., Shankar, S. and Bellotti, W.D. (2017) 'The interplay of production commercialisation and specialization', China Agricultural Economic Review, 9(4): 504-521.

Michler, J.D. and Josephson, A.L. (2017) 'To specialize or diversify: agricultural diversity and poverty dynamics in Ethiopia', World Development 89: 214-226.

MoA (Ministry of Agriculture) (2020) National Rice Development Strategy-II (2020-2030). Addis Ababa: Ministry of Agriculture.

MoANR (Ministry of Agriculture and Natural Resources) (2010) National Rice Research and Development Strategy of Ethiopia. Addis Ababa: Ministry of Agriculture and Natural Resources.

Muyanga, M. and Jayne, T.S. (2019) 'Revisiting the farm size-productivity relationship based on a relatively wide range of farm sizes: evidence from Kenya', American Journal of Agricultural Economics 101(4): 1140-1163.

Mussema, R., Kassa, B., Alemu, D. and Shahidur, R. (2015) 'Determinants of Crop Diversification in Ethiopia: Evidence from Oromia Region', Ethiopian Journal of Agricultural Sciences 25(2): 65-76.

Poulton, C. (2017) What is Agricultural Commercialisation, Why is it Important, and how do we Measure it? APRA Working Paper 6. Brighton: Future Agricultures Consortium. Available at: https://opendocs.ids.ac.uk/opendocs/ handle/20.500.12413/13560 (Accessed: 2 November 2021).

Poulton, C. (2018) 'Kilombero Stories', APRA Blog [online], 21 March. Available at: https://www.future-agricultures. org/blog/kilombero-stories/ (Accessed: 3 March 2020).

Sabates-Wheeler, R. (2018) 'Can Rice Commercialisation Transform Agrarian Society in Ethiopia', APRA Blog [online], 27 November. Available at: https://www.future-agricultures.org/blog/can-rice-commercialisationtransform-agrarian-society-in-ethiopia/ (Accessed: 2 November 2021).

Saha, A., Sabates-Wheeler, R. and Thompson, J. (2021) 'Insights into smallholder capacity for agricultural commercialisation: Evidence from four African contexts', The European Journal of Development Research, 1-46. 
Shahidur, R. and Lemma, S. (2011) Strategic Grain Reserves in Ethiopia: Institutional Design and Operational Performance. IFPRI Discussion Paper 01054. Washington, DC: International Food Policy Research Institute.

Tadesse, Z., Tadesse, T., Dejen, T. and Molla, T. (2019) 'Research on Rice Cultural Practices in Ethiopia', in: T. Tadesse, M. Atnaf, D. Alemu, T. Tadesse and K. Shiratori (eds.), Advances in Rice Research and Development in Ethiopia. Addis Ababa: Ethiopian Institute of Agricultural Research (EIAR).

Teamir, M. (2019) 'Rice Processing and Consumption Experiences: Implications for Research in Ethiopia', in: T. Tadesse, M. Atnaf, D. Alemu, T. Tadesse and K. Shiratori (eds.), Advances in Rice Research and Development in Ethiopia. Addis Ababa: Ethiopian Institute of Agricultural Research (EIAR).

Tipraqsa, P. and Schreinemachers, P. (2009) 'Agricultural commercialization of Karen Hill tribes in northern Thailand', Agricultural Economics 40(1): 43-53.

Ulimwengu, J. and Badibanga, T. (2012) The Sophistication and Diversification of the African Agricultural Sector: A Product Space Approach. IFPRI Discussion Paper 01156. West and Central Africa Office: International Food Policy Research Institute (IFPRI).

Wiggins, S., Argwings-Kodhek, G., Gebreselassie, S., Asuming-Brempong, S., Chirwa, E., Matita, M.M., Mode, N. and Mutabazi, K. (2014) Cautious Commercialisation. Findings from Village Studies in Ethiopia, Ghana, Kenya, Malawi \& Tanzania. Future Agricultures Working Paper 82. Brighton: Future Agricultures Consortium. Available at: https://assets.publishing.service.gov.uk/media/57a089aae5274a31e00001e6/FAC_Working_Paper_082.pdf (Accessed: 2 November 2021). 


\section{APPENDIX}

Table A1 - Summary of crops

\begin{tabular}{|l|l|l|l|l|l|}
\hline 1 & Rice & 11 & Fava bean & 21 & Pepper \\
\hline 2 & Teff & 12 & Grass pea (guaya) & 22 & Tomato \\
\hline 3 & Wheat & 13 & Chickpea & 23 & Other vegetable crops \\
\hline 4 & Barley & 14 & Other beans & 24 & Coffee \\
\hline 5 & Sorghum & 15 & Niger seed (nug) & 25 & Banana \\
\hline 6 & Millet & 16 & Sesame & 26 & Mango \\
\hline 7 & Maize & 17 & Other oil crops & 27 & Hop (gesho) \\
\hline 8 & Other cereals & 18 & Irish potato & 28 & Eucalyptus \\
\hline 9 & Haricot bean & 19 & Onion & 29 & Other crops \\
\hline 10 & Lentil (miser) & 20 & Garlic & 30 & No crop planted \\
\hline
\end{tabular}

Source: Authors' own, using data from APRA rice farmers' survey (2018) 
Table A2 - OLS results for total sample

\begin{tabular}{|c|c|c|c|c|}
\hline & 1 & 2 & 3 & 4 \\
\hline Specialisation & $\begin{array}{l}0.078^{\star \star} \\
(0.034)\end{array}$ & $\begin{array}{l}0.053 \\
(0.040)\end{array}$ & $\begin{array}{l}0.033 \\
(0.043)\end{array}$ & $\begin{array}{l}0.003 \\
(0.043)\end{array}$ \\
\hline Total land size (ha) & $\begin{array}{l}0.155^{\star \star \star} \\
(0.027) \\
\end{array}$ & $\begin{array}{l}0.126^{\star \star \star} \\
(0.033) \\
\end{array}$ & $\begin{array}{l}0.126^{\star \star \star} \\
(0.033) \\
\end{array}$ & $\begin{array}{l}0.109^{\star \star \star} \\
(0.033)\end{array}$ \\
\hline Total land size (ha) ${ }^{2}$ & $\begin{array}{l}-0.027^{\star \star \star \star} \\
(0.007)\end{array}$ & $\begin{array}{l}-0.024^{\star \star \star} \\
(0.007)\end{array}$ & $\begin{array}{l}-0.024^{\star \star \star} \\
(0.007)\end{array}$ & $\begin{array}{l}-0.021^{\star \star \star} \\
(0.007)\end{array}$ \\
\hline \multicolumn{5}{|l|}{ Control variables } \\
\hline Age of household head & $\begin{array}{l}0.001^{\star \star} \\
(0.001)\end{array}$ & $\begin{array}{l}0.002^{\star \star} \\
(0.001) \\
\end{array}$ & $\begin{array}{l}0.002^{\star \star \star} \\
(0.001) \\
\end{array}$ & $\begin{array}{l}0.001^{\star \star} \\
(0.001)\end{array}$ \\
\hline Household size & $\begin{array}{l}0.006 \\
(0.005)\end{array}$ & $\begin{array}{l}0.005 \\
(0.005)\end{array}$ & $\begin{array}{l}0.004 \\
(0.005)\end{array}$ & $\begin{array}{l}0.002 \\
(0.005)\end{array}$ \\
\hline Female head & \begin{tabular}{|l|}
0.014 \\
$(0.025)$ \\
\end{tabular} & $\begin{array}{l}0.022 \\
(0.025) \\
\end{array}$ & \begin{tabular}{|l|}
0.024 \\
$(0.024)$ \\
\end{tabular} & $\begin{array}{l}0.014 \\
(0.025) \\
\end{array}$ \\
\hline Max education level of Household (years) & $\begin{array}{l}-0.006^{\star \star} \\
(0.002)\end{array}$ & $\begin{array}{l}-0.006^{\star \star} \\
(0.002)\end{array}$ & $\begin{array}{l}-0.006^{\star \star} \\
(0.002)\end{array}$ & $\begin{array}{l}-0.005^{\star} \\
(0.002)\end{array}$ \\
\hline MPI & $\begin{array}{l}0.001^{*} \\
(0.001)\end{array}$ & $\begin{array}{l}0.001^{*} \\
(0.001)\end{array}$ & $\begin{array}{l}0.001^{*} \\
(0.001)\end{array}$ & $\begin{array}{l}0.001 \\
(0.001)\end{array}$ \\
\hline Farming experience of rice head (years) & & $\begin{array}{l}-0.002 \\
(0.001)\end{array}$ & $\begin{array}{l}-0.002 \\
(0.001) \\
\end{array}$ & $\begin{array}{l}-0.002 \\
(0.001)\end{array}$ \\
\hline Total labour & & $\begin{array}{l}0.011 \\
(0.013) \\
\end{array}$ & $\begin{array}{l}0.009 \\
(0.013)\end{array}$ & $\begin{array}{l}0.003 \\
(0.013)\end{array}$ \\
\hline Asset Index & & \begin{tabular}{|l|}
0.077 \\
$(0.053)$
\end{tabular} & $\begin{array}{l}0.057 \\
(0.055)\end{array}$ & $\begin{array}{l}0.026 \\
(0.056)\end{array}$ \\
\hline Growing cash crops & & & $\begin{array}{l}-0.021 \\
(0.021) \\
\end{array}$ & \begin{tabular}{|l|}
-0.026 \\
$(0.021)$ \\
\end{tabular} \\
\hline Access to irrigation & & & $\begin{array}{l}0.029^{\star} \\
(0.017)\end{array}$ & $\begin{array}{l}0.033^{\star} \\
(0.017)\end{array}$ \\
\hline Extension service & & & $\begin{array}{l}0.028 \\
(0.019)\end{array}$ & $\begin{array}{l}0.021 \\
(0.019) \\
\end{array}$ \\
\hline Member cooperative & & & & $\begin{array}{l}-0.010 \\
(0.017)\end{array}$ \\
\hline Distance from market (in minutes) & & & & $\begin{array}{l}0.020^{\star * \star} \\
(0.006)\end{array}$ \\
\hline Rice land productivity & & & & $\begin{array}{l}0.057^{\star \star} \\
(0.027)\end{array}$ \\
\hline Libokemkem & $\begin{array}{l}-0.015 \\
(0.016)\end{array}$ & $\begin{array}{l}-0.008 \\
(0.016)\end{array}$ & $\begin{array}{l}-0.006 \\
(0.016)\end{array}$ & $\begin{array}{l}-0.012 \\
(0.017)\end{array}$ \\
\hline Dera & $\begin{array}{l}0.034 \\
(0.035)\end{array}$ & $\begin{array}{l}0.025 \\
(0.037)\end{array}$ & $\begin{array}{l}0.021 \\
(0.037)\end{array}$ & $\begin{array}{l}0.019 \\
(0.037)\end{array}$ \\
\hline $\begin{array}{l}\text { Observations } \\
\text { R-squared }\end{array}$ & $\begin{array}{l}721 \\
0.693\end{array}$ & $\begin{array}{l}721 \\
0.695\end{array}$ & $\begin{array}{l}720 \\
0.697\end{array}$ & $\begin{array}{l}717 \\
0.707\end{array}$ \\
\hline
\end{tabular}

Robust standard errors in parentheses

${ }^{\star \star \star} p<0.01,{ }^{\star *} p<0.05,{ }^{*} p<0.1$

Source: Authors' own, using data from APRA rice farmers' survey (2018) 
Sabates-Wheeler, R., Carreras, M. and Alemu, D. (2021) How Does Land Size Mediate the Relationship Between Specialisation and Commercialisation? Lessons From Rice Farming in the Fogera Plain of Ethiopia. APRA Working Paper 78. Brighton: Future Agricultures Consortium

(c) APRA 2021

ISBN: 978-1-78118-903-0

DOI: 10.19088/APRA.2021.047

\section{(cc) BY-NC-ND}

This is an Open Access report distributed under the terms of the Attribution-Non Commercial-No Derivs 4.0 Unported (CC BY-NC-ND 4.0) Attribution - You must give appropriate credit, provide a link to the license, and indicate if changes were made. You may do so in any reasonable manner, but not in any way that suggests the licensor endorses you or your use. NonCommercial — You may not use the material for commercial purposes. NoDerivatives - If you remix, transform, or build upon the material, you may not distribute the modified material. You are free to: Share - copy and redistribute the material in any medium or format.

https://creativecommons.org/licenses/by-nc-nd/4.0/legalcode

If you use the work, we ask that you reference the APRA website (www.future-agricultures.org/apra/) and send a copy of the work or a link to its use online to the following address for our archive: APRA, Future Agricultures Consortium, University of Sussex, Brighton BN1 9RE, UK (apra@ids.ac.uk)

All APRA Working Papers go through a review process before publication.

\section{@c) creative}

\section{DO YOU HAVE COMMENTS ON THIS PAPER?}

We would welcome your feedback on this working paper!

To provide brief comments, please follow this link to our short APRA Working Paper Feedback form: https://goo.gl/forms/1iVnXhhrlGesfR9

Agricultural Policy Research in Africa (APRA) is a programme of the Future Agricultures Consortium (FAC) which is

generating new evidence and policy-relevant insights on more inclusive pathways to agricultural commercialisation in sub-Saharan Africa. APRA is funded with UK aid from the UK Foreign, Commonwealth \&

Development Office (FCDO) and will run from 2016-2022.

The APRA Directorate is based at the Institute of Development Studies (IDS), UK (www.ids.ac.uk), with regional hubs at the Centre for African Bio-Entrepreneurship (CABE), Kenya, the Institute for Poverty, Land and Agrarian Studies (PLAAS), South Africa, and the University of Ghana, Legon. It builds on more than a decade of research and policy engagement work by the Future Agricultures Consortium (www.future-agricultures.org) and involves more than 100 researchers and communications professionals in Africa, UK, Sweden and USA. 